\section{University of New Hampshire}

Carsey School of Public Policy

\section{CARSEY RESEARCH}

National Issue Brief \#143

Summer 2019

\title{
Climate-Change Views of New Hampshire Primary Voters
}

Lawrence C. Hamilton

$\mathrm{I}$ n April 2019 the Granite State Poll asked 549 New Hampshire residents whether they planned to vote in the state's 2020 presidential primary election and, if so, which candidate they favored. ${ }^{1}$ In addition, using a standard question that has been asked in more than 40,000 interviews on regional and national surveys since $2010,{ }^{2}$ it also asked residents about their views on climate change. Scientists identify human-caused climate change as a major threat, ${ }^{3}$ but it has received relatively little attention in U.S. presidential campaigns. The coincidental placement of primary-election and climate-change questions on the same poll provides an opportunity to explore how different candidates' supporters line up on this critical issue.

Of the 549 New Hampshire residents interviewed for this poll, 492 said they planned to vote in the primary. Of those, 444 had already decided upon which party: 195 Republicans and 249 Democrats. Figure 1 charts responses from Democrats when asked who they would vote for if the primary election were held today. Thirty percent chose Bernie Sanders, while Joe Biden (who had not yet announced he was running) and Pete Buttigieg also received double-digit support. Other responses spread out among the field of 17 candidates.

Our climate-change question asked:

Which of the following three statements do you think is more accurate?

- Climate change is happening now, caused mainly by human activities.

- Climate change is happening now, but caused mainly by natural forces.

- Climate change is NOT happening now.

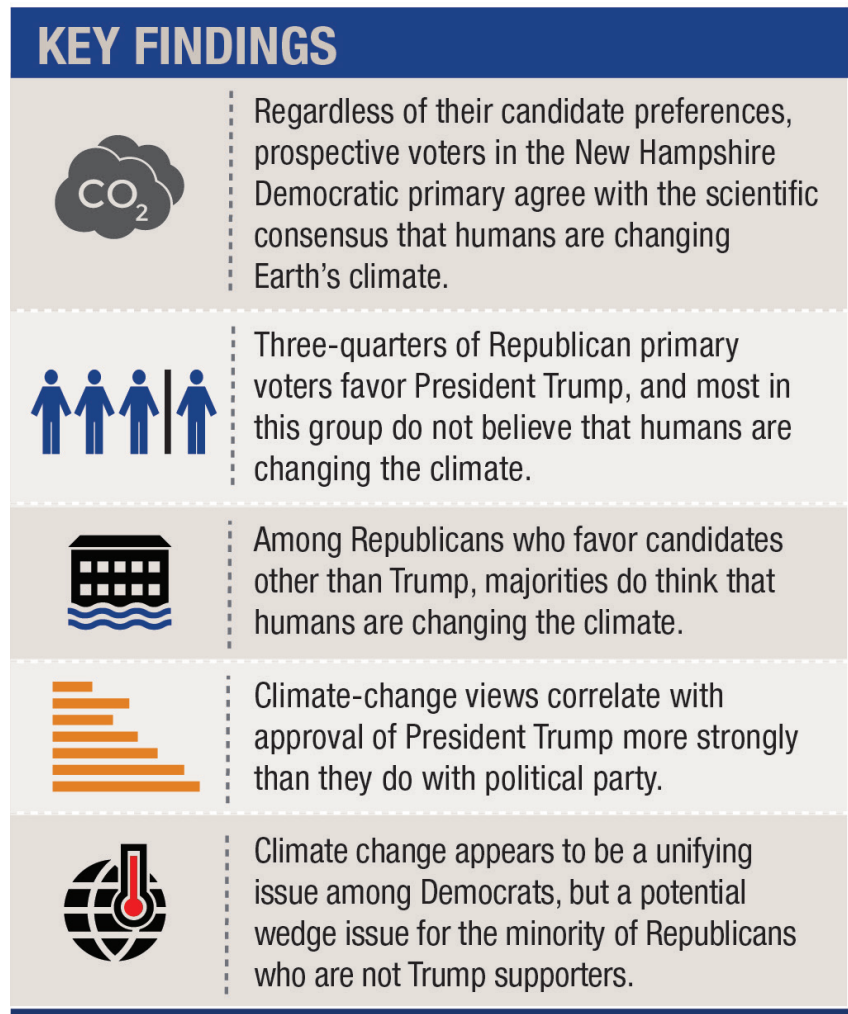

The first choice listed (rotated in actual interviews), "Climate change is happening now, caused mainly by human activities," corresponds to the overwhelming, evidence-based consensus among scientists with relevant expertise. ${ }^{4}$ Nationwide and New Hampshire surveys typically find that more than 60 percent of the public agrees. ${ }^{5}$ On this April 2019 poll, 64 percent chose the now/human response, while 27 percent accepted that climate change is happening but caused mainly by natural forces. Only 3 percent thought climate is not changing, and 5 percent said they did not know. 
Large majorities of Democrats agree that humans are changing the climate, regardless of which candidate they support.

As Figure 2 shows, large majorities of Democrats agree that humans are changing the climate, regardless of which candidate they support. Results range from 62 to 100 percent agreement, or from 82 to 100 percent if we focus on the top eight candidates (including "undecided") who polled at least 3 percent. Minor differences among top candidates' supporters in Figure 2 are not statistically significant, meaning they could simply be chance variations. Support for lower-ranked candidates in this poll was spread thinly, six people or fewer per candidate. With so few in each group we might expect to see erratic variations. Instead, the results are notably consistent. Democrats appear largely united on the reality of human-caused climate change.

Republican responses paint a contrasting picture of greater unity on candidates but less unity on climate. Figure 3 charts their choices if the primary election were held today. Donald Trump is the favorite by far, with 76 percent support. He is trailed by John Kasich (10 percent), undecided ( 8 percent), and Bill Weld (5 percent).

Figure 4 depicts what fraction of each Republican candidate's supporters think that human activities are changing the climate. Only about one-fourth of Trump supporters agree, but the fraction rises to a majority (55 percent) among undecided Republicans,

\section{FIGURE 1: (DEMOCRATS) IF THE NEW HAMPSHIRE PRIMARY ELECTION WERE HELD TODAY, WHO WOULD YOU VOTE FOR?}

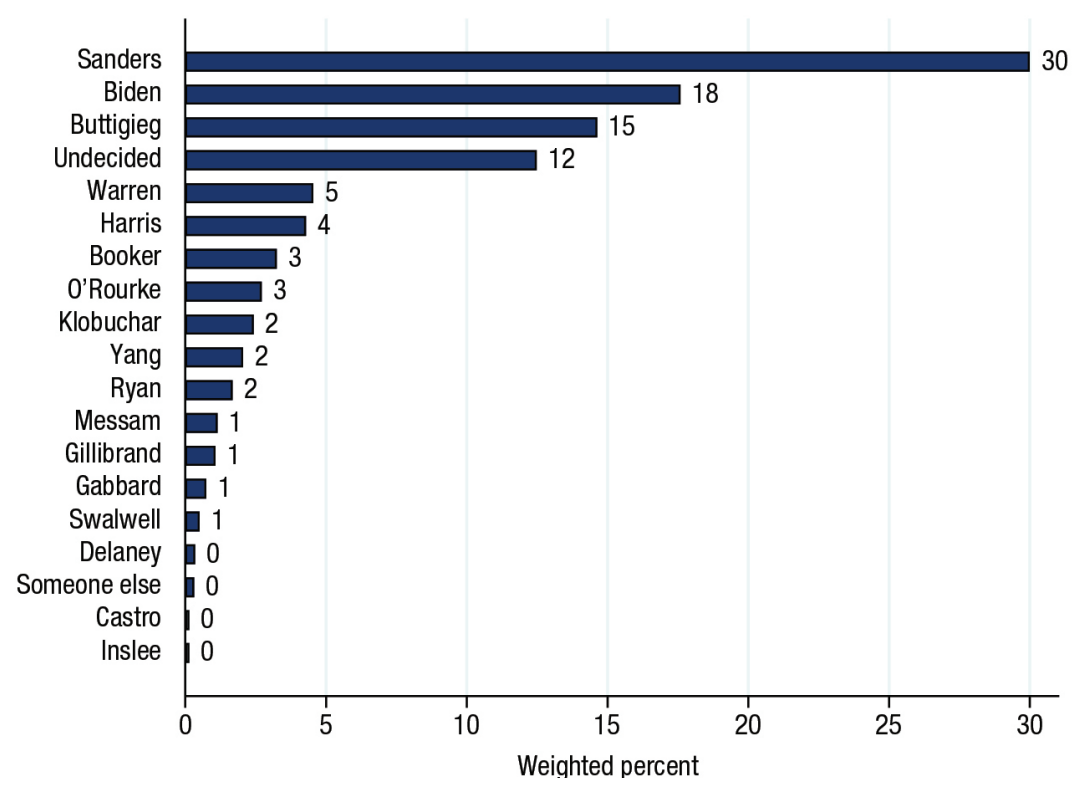

Source: Granite State Poll, April 2019

FIGURE 2: (DEMOCRATS) PERCENTAGE OF EACH CANDIDATE'S SUPPORTERS AGREEING THAT CLIMATE CHANGE IS HAPPENING NOW, CAUSED MAINLY BY HUMAN ACTIVITIES.

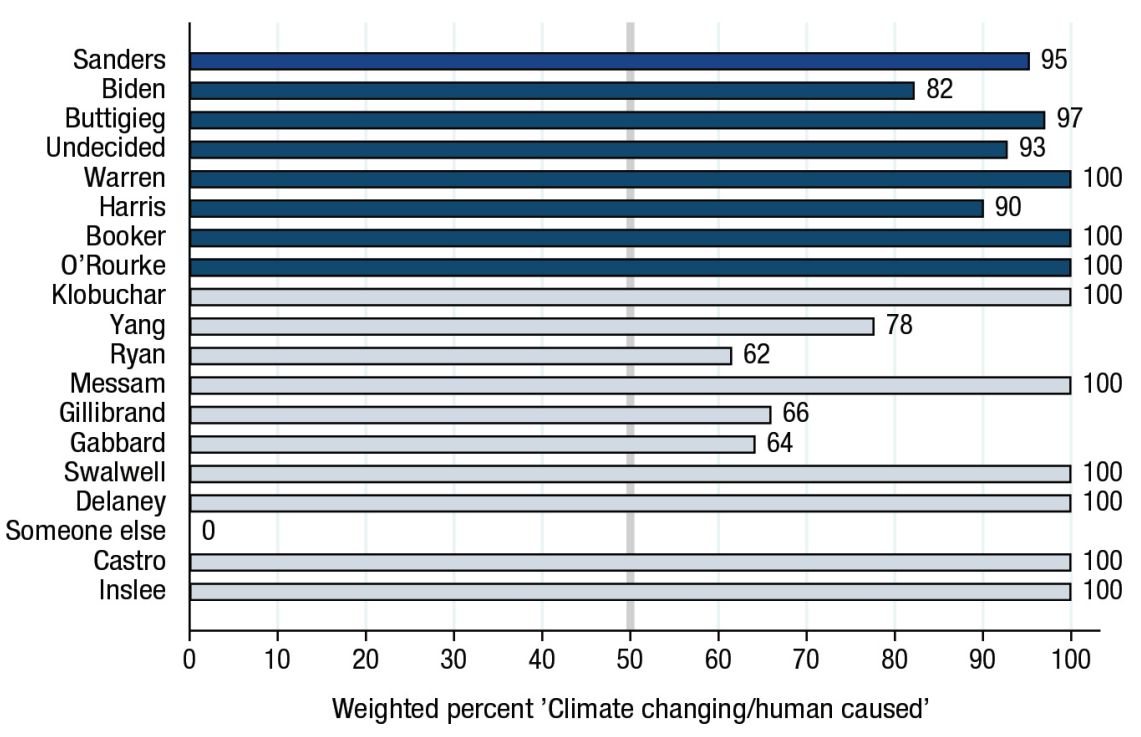

Note: Darker bars emphasize candidates who polled at least 3 percent.

Source: Granite State Poll, April 2019 
FIGURE 3: (REPUBLICANS) IF THE NEW HAMPSHIRE PRIMARY ELECTION WERE HELD RIGHT NOW, WHO WOULD YOU VOTE FOR?

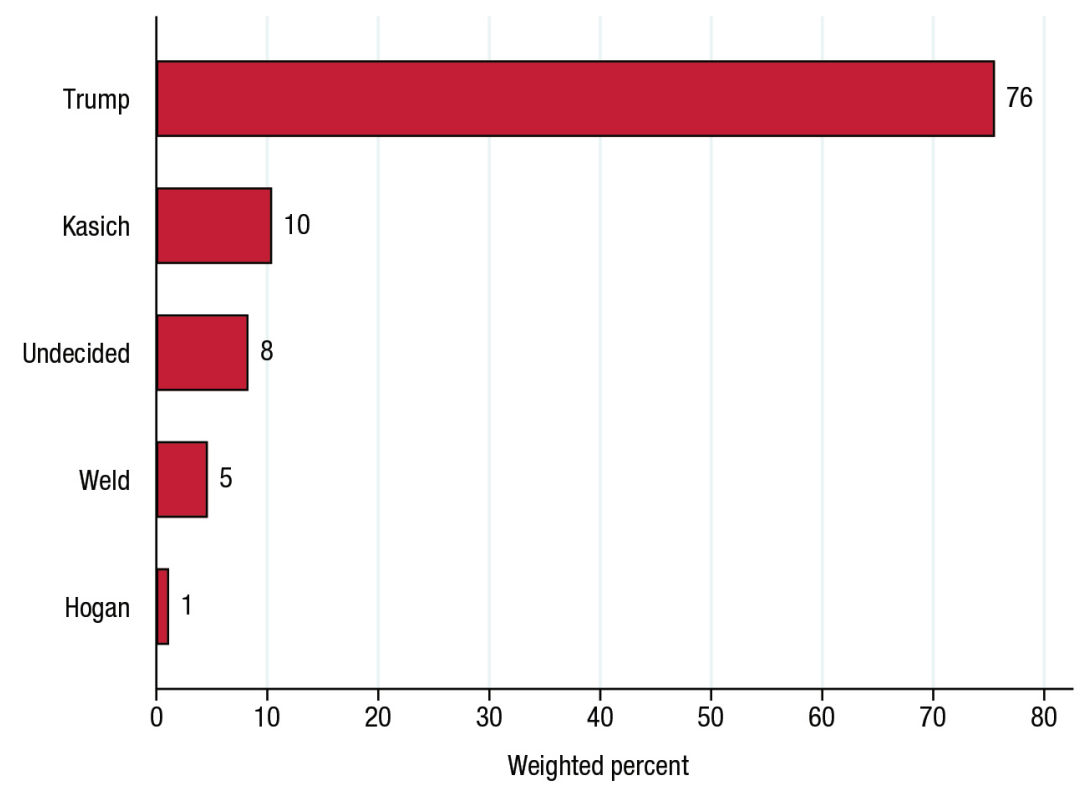

Source: Granite State Poll, April 2019

\section{FIGURE 4: PERCENTAGE OF REPUBLICAN CANDIDATES' SUPPORTERS AGREEING THAT CLIMATE CHANGE IS HAPPENING NOW, CAUSED MAINLY BY HUMAN ACTIVITIES.}

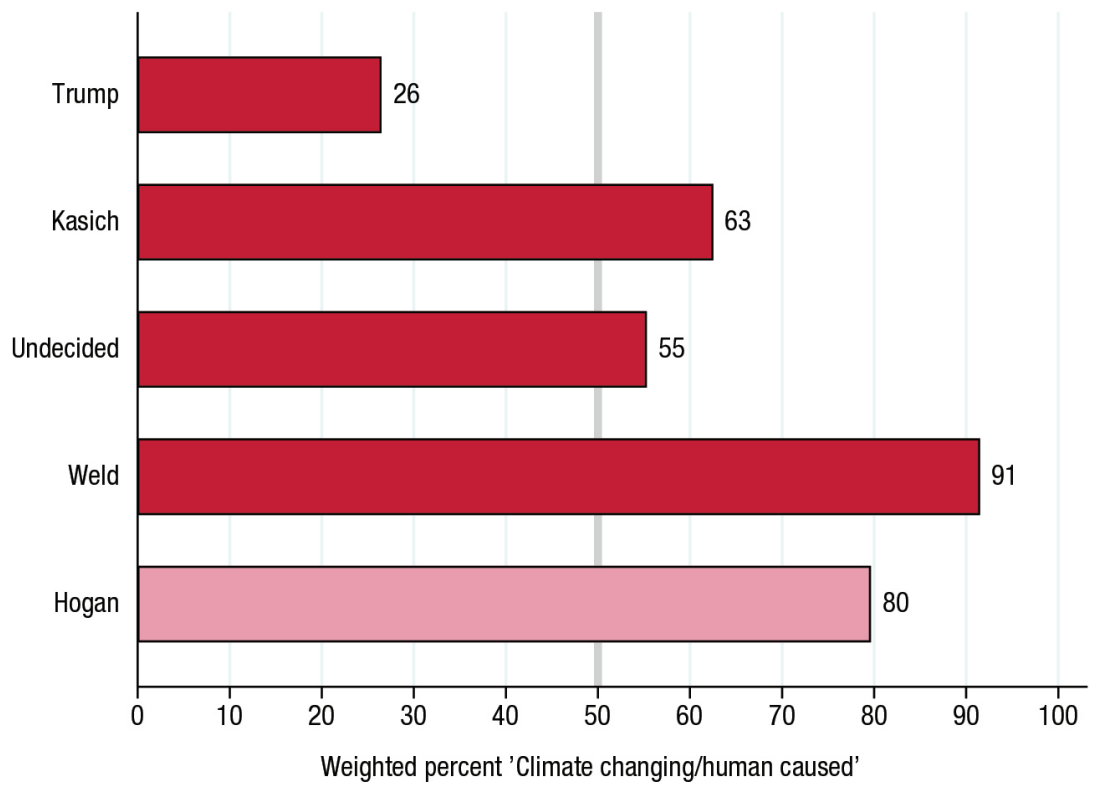

Note: Darker bars emphasize candidates who polled at least 3 percent. Source: Granite State Poll, April 2019 and even higher among supporters of Kasich (63 percent) and Weld (91 percent). Combining all the non-Trump responses, who together make up 24 percent of the Republican sample, reveals a stark contrast: 26 percent of Trump supporters agree that humans are changing the climate, compared with 64 percent of the Republicans who do not favor Trump.

Combining all the non-Trump responses, who together make up 24 percent of the Republican sample, reveals a stark contrast: 26 percent of Trump supporters agree that humans are changing the climate, compared with 64 percent of the Republicans who do not favor Trump.

The correlation between climatechange views and political party identification is well known from many surveys ${ }^{6}$ including the Granite State Poll. ${ }^{7}$ Republicans are more likely than either Democrats or independents to disbelieve that humans are changing the climate. The divisions among Republicans seen in Figure 4 suggest a new proposition, however: that climatechange views might correlate more strongly with Trump approval than they do with political party itself. In the Granite State Poll data, this turns out to be true.

Figure 5 charts responses to a standard question: "Generally speaking, do you approve or disapprove of the way Donald Trump is handling his job as president?" The pattern is distinctly bimodal (twopeaked), with 27 percent strongly approving, 44 percent strongly disapproving, and the remaining 29 percent spread out in between. 
For each level of Trump approval, Figure 6 graphs the percentage of respondents who agree that humans are changing the climate. The gradient is striking: we see a 68-point range, from 25 percent among those who strongly approve of President Trump to 93 percent among those who strongly disapprove. Majorities of neutral respondents, as well as those who disapprove, align with scientists on the reality of human-caused climate change. (In contrast, this survey finds a range of just 52 points between the climate-change views of strong Republicans and strong Democrats.) Similar patterns occurred on earlier Granite State Polls going back to February 2017, almost 5,000 additional interviews, which also asked about Trump approval and climate change. Across all of these polls, climate-change views correlate more strongly with Trump approval than they do with political party identification. That conclusion fits with earlier observations about distinctive views on science ${ }^{8}$ and environmental ${ }^{9}$ topics among Trump supporters.

The April 2019 poll results show Democratic primary voters united on the reality of human-caused climate change. Democratic candidates differ in how much they emphasize this issue, or which policies they favor, but most of their supporters start out in agreement that the problem exists. Republicans appear more divided on this issue. Three-fourths favor Donald Trump as their candidate, and most of those do not believe humans are changing the climate. Among the minority of Republicans who are undecided or prefer other candidates for president, however, most do accept that humans are changing the climate. For this small group, climate change is potentially a wedge issue separating them from other Republicans.

\section{FIGURE 5: DO YOU APPROVE OR DISAPPROVE OF THE WAY DONALD TRUMP IS HANDLING HIS JOB AS PRESIDENT?}

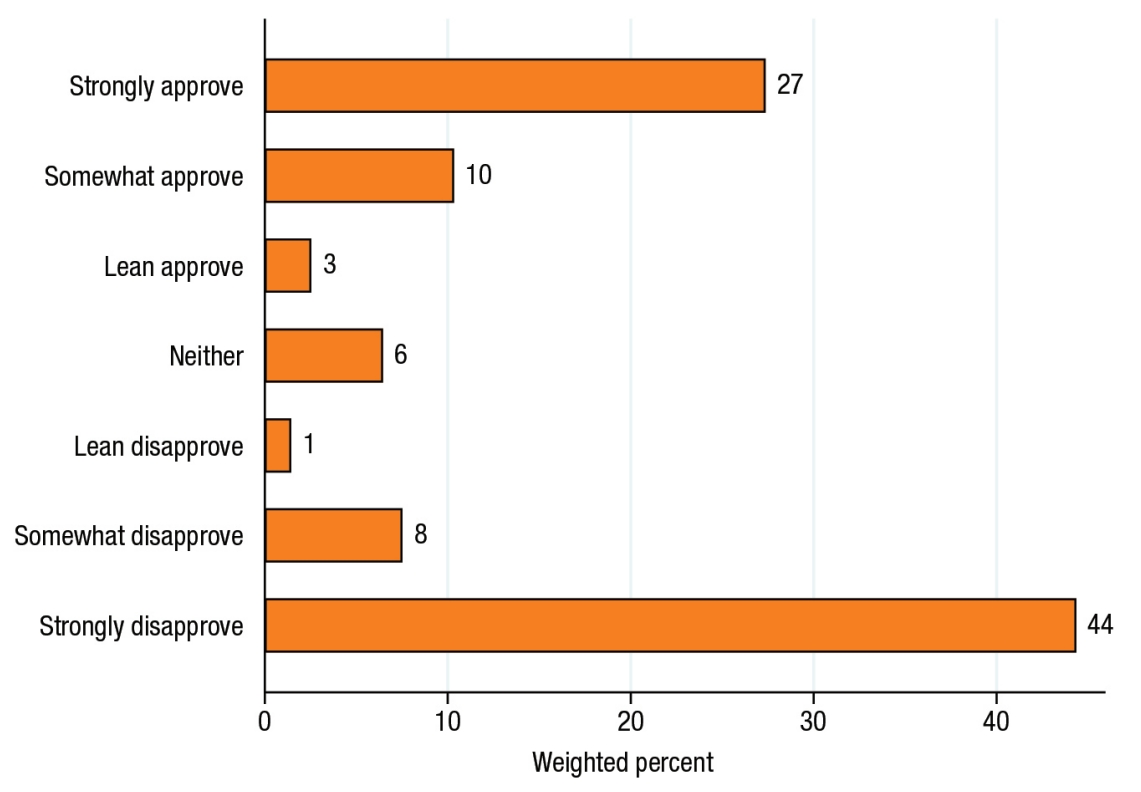

Source: Granite State Poll, April 2019

\section{FIGURE 6: PERCENTAGE AT DIFFERENT LEVELS OF TRUMP APPROVAL AGREEING THAT CLIMATE CHANGE IS HAPPENING NOW, CAUSED MAINLY BY HUMAN ACTIVITIES.}

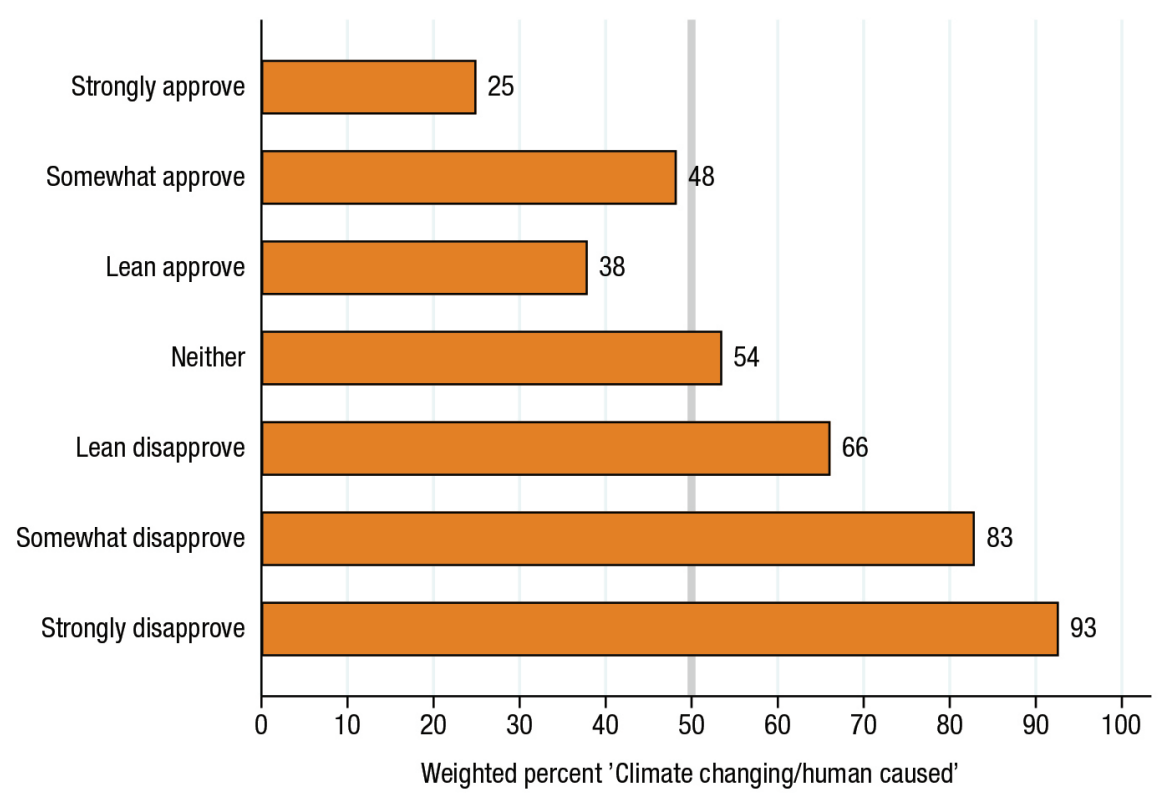

Source: Granite State Poll, April 2019 


\section{End not es}

1. Details of this poll, and analysis of candidate preferences, have been published in a report from the Survey Center at the University of New Hampshire; see S.P. McKinley, Z.S. Azem, and A.E. Smith, "Sanders Increases Lead Over Biden as Buttigieg Vaults Into Top 3; Little Support for Potential Challengers to Trump" (Durham, NH: University of New Hampshire Survey Center, 2019), https:// scholars.unh.edu/cgi/viewcontent. cgi? article $=1557 \&$ context=survey center_polls.

2. L.C. Hamilton, J. Hartter, and E. Bell, "Generational Aspects of U.S. Public Opinion on Renewable Energy and Climate Change," presentation at workshop "Sharing the Burden? Public Values, Attitudes, and Preferences About Climate Policy," Institute for Future Studies, Stockholm, Sweden, 2019, https://scholars.unh.edu/soc_ facpub/615/.

3. U.S. Global Change Research Program, Climate Science Special Report: Fourth National Climate Assessment (NCA4), Vol. I, U.S.GCRP, https://science2017.globalchange.gov.

4. J. Cook, N. Oreskes, P.T. Doran, W.R.L. Anderegg, B. Verheggen, E.W. Maibach, J.S. Carlton, S. Lewandowsky, A.G. Skuce, S.A. Green, D. Nuccitelli, P. Jacobs, M. Richardson, B. Winkler, R. Painting, and K. Rice, "Consensus on Consensus: A Synthesis of Consensus Estimates on Human-Caused Global Warming," Environmental Research Letters 11, no. 4 (2016), doi:10.1088/1748-9326/11/4/048002.
5. L.C. Hamilton, E. Bell, J. Hartter, and J.D. Salerno, "A Change in the Wind? U.S. Public Views on Renewable Energy and Climate Compared," Energy, Sustainability and Society 8, no. 11 (2018), doi: 10.1186/s13705-018-0152-5.

6. L.C. Hamilton, J. Hartter, M. LemckeStampone, D.W. Moore, and T.G. Safford, "Tracking Public Beliefs About Anthropogenic Climate Change," PLOS ONE 10, no. 9 (2015): e0138208, doi: 10.1371/journal.pone.0138208.

7. J.L Bolin and L.C. Hamilton, "The News You Choose: News Media Preferences Amplify Views on Climate Change," Environmental Politics 27, no. 3 (2018): 455-76, doi: 10.1080/09644016.2018.1423909.

8. L.C. Hamilton, "Where Is the North Pole? An Election-Year Survey on Global Change" (Durham, NH: Carsey School of Public Policy, 2016), http:// scholars.unh.edu/carsey/285/.

9. L.C. Hamilton, "On Renewable Energy and Climate, Trump Voters Stand Apart" (Durham, NH: Carsey School of Public Policy, 2017), http:// scholars.unh.edu/carsey/293/. 


\section{About the Author}

Lawrence C. Hamilton is professor of sociology and a senior fellow at the Carsey School of Public Policy at the University of New Hampshire (https://carsey.unh. edu/person/lawrence-hamilton).

\section{A cknowledgments}

Climate-change climate questions on the Granite State Poll have been supported by the Carsey School of Public Policy and the Sustainability Institute at the University of New Hampshire.

\section{Tu University of New Hampshire}

Carsey School of Public Policy

The Carsey School of Public Policy at the University of New Hampshire is nationally recognized for its research, policy education, and engagement. The school takes on the pressing issues of the twenty-first century, striving for innovative, responsive, and equitable solutions.

Huddleston Hall • 73 Main Street • Durham, NH 03824

(603) 862-2821

TTY Users: DIAL 7-1-1 OR 1-800-735-2964 (RELAY N.H.)

carsey.unh.edu 